\title{
Some population characteristics of Oxynoemacheilus angorae (Steindachner, 1897) from the Perşembe Plateau meandering streams in Ordu, Turkey
}

\author{
Serdar Yedier, Derya Bostanci, Nazmi Polat
}

Received - 19 January 2021/Accepted - 21 June 2021. Published online: 30 June 2021; @Inland Fisheries Institute in Olsztyn, Poland Citation: Yedier, S., Bostanci, D., Polat, N. (2021). Some population characteristics of Oxynoemacheilus angorae (Steindachner, 1897) from the Perşembe Plateau meandering streams in Ordu, Turkey. Fisheries Aquatic \& Life, 29, 100-107

\begin{abstract}
The aim of the current study was to determine the length-weight relationship (LWR) and length-length relationship (LLR) with condition factor (K) values for Oxynoemacheilus angorae from the Perşembe Plateau meandering streams in Ordu, Turkey. A total of 65 fish specimens, which were caught with electrofishing gear, were examined. Fish standard length (SL), fork length (FL), total length (TL), and body weight (W) were determined. There were no statistical differences between the measurements of male and female $O$. angorae specimens; therefore, the female and male specimens were evaluated together in the current study. The LWR equation and determination coefficient of $O$. angorae were $\mathrm{W}=0.014 \mathrm{TL}^{2.7359}\left(\mathrm{r}^{2}=0.9659\right)$. The $95 \%$ confidence interval of the $b$ value for the $O$. angorae specimens from the Perşembe Plateau meandering streams was 2.7261 to 2.7435 . In the present study, it was determined that $O$. angorae specimens showed negative allometric growth. Calculations of $O$. angorae TL-SL, TL-FL, and FL-SL relationship equations and determination coefficients were as follows: $\mathrm{TL}=0.2091+1.1646$ SL, $\left(\mathrm{r}^{2}=0.986\right) ; \mathrm{TL}=$ $0.1341+1.0301 \mathrm{FL}\left(\mathrm{r}^{2}=0.9914\right)$; and FL $=0.0998+1.1261$ SL, $\left(r^{2}=0.9868\right)$, respectively. A new maximum total length was recorded for $O$. angorae in this study. The average
\end{abstract}

S. Yedier [ $\left.\Xi^{\circ}\right]$, D. Bostanci

Ordu University, Faculty of Arts and Sciences, 52200 Ordu-Turkey

E-mail: serdar7er@gmail.com

N. Polat

Ondokuz Maý1s University, Faculty of Arts and Sciences, 55139

Samsun-Turkey condition factor value of $O$. angorae was 0.9954 . This value could have indicated that this species was encountering some problems in this habitat. The $O$. angorae parameters determined were the first data reported for the Perşembe Plateau meandering streams in Ordu, Turkey (Middle Black Sea Region).

Keywords: Length-weight relationship, length-length relationship, growth, condition factor, Middle Black Sea Region

\section{Introduction}

Length-length (LLR) and length-weight (LWR) relationships of fish species are important in fisheries and fish biology (Yilmaz and Polat 2011). They permit estimating the body weight of fish from total length and the total length of fish from standard length by establishing mathematical relationships among these variables (Sarkar et al. 2008). Moreover, LWR and LLR relationships are also used to assess fish stocks, and they provide information on the growth status of fish species in different habitats (Yilmaz et al. 2010). The condition factor is one of the most important parameters related to fish body shape, and this parameter can provide information about the development of fish species in different 
habitats (Froese 2006). In this way, researchers can compare fish populations belonging to the same species in different habitats based on condition factors. Thus, data on the impact of habitat differences on the fish can be provided (Yedier et al. 2019).

Angorae loach, Oxynoemacheilus angorae, is a member of the family Nemacheilidae. This species is widespread from Jordan to Turkey (Froese and Pauly 2020). O. angorae is one of the native freshwater fish species in Turkish ichthyofauna. Moreover, the species is distributed in both lentic and lotic habitats in Turkey. The conservation status of the species on the IUCN Red List is that of least concern (LC) (Freyhof 2014). The problems caused by eutrophication, contamination, and decreases in water levels from dam construction are the most important factors endangering the species (Froese and Pauly 2020). There are few studies in the literature on the length-length and the length-weight relationships with condition factor of this species from different aquatic habitats (Golzarianpour et al. 2011, Hasankhani et al. 2014). The species was also reported in many Turkish inland waters such as Balıklı Stream (Gaygusuz et al. 2013), Söğütözü Creek (Erk'akan et al. 2014), Kılıçözü Stream (Yazıcığlu and Yazıc1 2016), Kirmir Stream (Zencir and Korkmaz 2016), the Kizılırmak River Basin (Birecikligil et al. 2016), and Asartepe Dam Lake (Saylar et al. 2020). There are very few studies on this species compared to other native fish species. Additionally, studies focused on the biology and population characteristics of this species are quite limited, and there are no studies on the length-length and length-weight relationships with condition factor of $O$. angorae from Ordu inland waters.

Therefore, the main objective of the current study was to determine the length-length, length-weight relationships with condition factor of $O$. angorae inhabiting the Perşembe Plateau meandering streams in Ordu, Turkey. The current study was the first to be conducted on the length-length and length-weight relationships with condition factor of $O$. angorae from Ordu inland waters.

\section{Materials and methods}

The Perşembe Plateau is one of the tourism centers of Ordu Province, Turkey, with unique meandering streams located at an altitude of 1,500 meters, which are some of the best examples of meanders in the country. Sampling was conducted in six of these meandering streams on the Perşembe Plateau, and $O$. angorae specimens were caught with a Samus-725MS (Fig. 1). The body weight (W) of the fish specimens was recorded to the nearest $0.01 \mathrm{~g}$ and standard length (SL), fork length (FL), and total length (TL) were measured to the nearest $0.1 \mathrm{~cm}$ (Fig. 2). The length-weight relationship of $O$. angorae
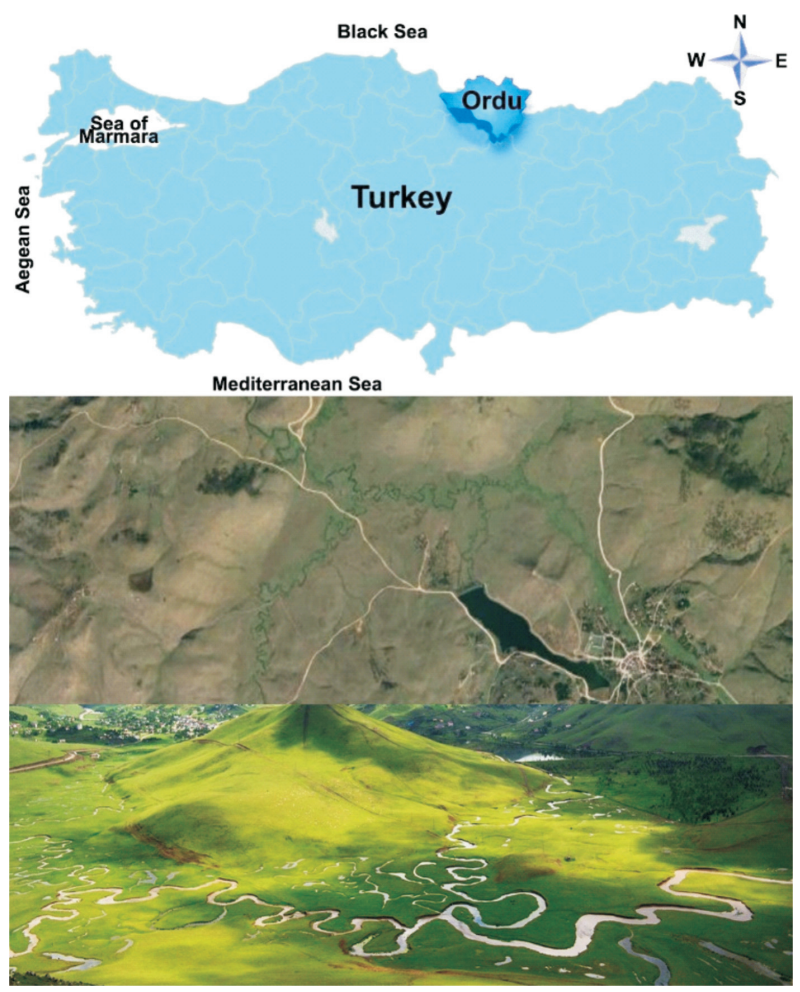

Figure 1. Map of the study area.

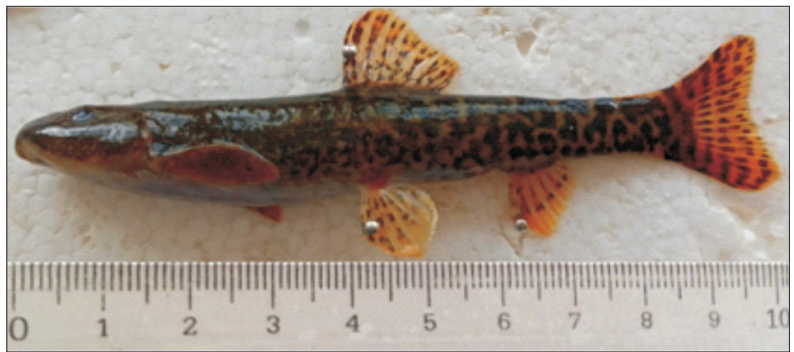

Figure 2. Oxynoemacheilus angorae specimens caught during sampling. 
Table 1

Descriptive statistics of morphometric measurements of Oxynoemacheilus angorae from the Perşembe Plateau meandering streams in Ordu, Turkey

\begin{tabular}{lllllll}
\hline \hline Morphometric measurements & $\mathrm{n}$ & Mean \pm SE & SD & $\min$ & $\max$ & $\begin{array}{c}\text { Coefficient of } \\
\text { variation \% }\end{array}$ \\
\hline \hline Body weight $(\mathrm{g})$ & 65 & $3.41 \pm 0.164$ & 1.324 & 1.20 & 7.51 & 38.80 \\
Total length $(\mathrm{cm})$ & & $7.34 \pm 0.123$ & 0.994 & 5.3 & 10.0 & 13.55 \\
Fork length $(\mathrm{cm})$ & & $6.99 \pm 0.119$ & 0.961 & 5.1 & 9.6 & 13.74 \\
Standard length $(\mathrm{cm})$ & & $6.13 \pm 0.105$ & 0.848 & 4.4 & 8.4 & 13.85 \\
\hline \hline
\end{tabular}

n: sample size; SE: standard error; min and max: minimum and maximum values, respectively.

inhabiting these streams was calculated with the equation $\mathrm{W}=\mathrm{aL}$, where $\mathrm{W}$ is fish body weight $(\mathrm{g}), \mathrm{L}$ is fish total length $(\mathrm{cm}), b$ is the slope, and $\mathrm{a}$ is the intercept (Bagenal and Tesch 1978). The $b$-values obtained from the length-weight relationship were tested using the t-test, and these results concerning $b$ values were used when determining the growth type of this species. A 95\% confidence interval (95\% CI) of the $b$ value was also calculated for the $O$. angorae specimens caught. The linear regression model $\mathrm{y}=$ $\mathrm{a} \pm \mathrm{bx}$ was used to determine the TL-SL, TL-FL, and FL-SL relationships. The quality of the linear regression model was evaluated using the determination coefficient $\left(\mathrm{r}^{2}\right)$ for $O$. angorae specimens. Fulton's condition factor $(\mathrm{K})$ was calculated with the following equation: $\mathrm{K}=100^{*}\left(\mathrm{~W} / \mathrm{L}^{3}\right)$, where $\mathrm{W}$ is fish body weight $(\mathrm{g})$, and $\mathrm{L}$ is fish total length $(\mathrm{cm})$ (Ricker 1975). Minitab 16 was used for all statistical analyses.

\section{Results}

In the current study, a total of 65 individuals were captured with electrofishing gear of which 37 (56.92\%) were female and 28 (43.08\%) were male. The $O$. angorae specimen weights $(\mathrm{W})$ ranged from $1.20 \mathrm{~g}$ to $7.51 \mathrm{~g}$, and standard length (SL), fork length (FL), and total length (TL) ranged between $4.4-8.4 \mathrm{~cm}, 5.1-9.6 \mathrm{~cm}$, and $5.3-10 \mathrm{~cm}$, respectively. The average total length of $O$. angorae individuals was $7.34 \pm 0.123 \mathrm{~cm}$ (Table 1 ). The average weight of the species was $3.41 \pm 0.164 \mathrm{~g}$ (Table 1$)$. In the present study, the largest total length was 10.0 $\mathrm{cm}$ and the smallest total length was $5.3 \mathrm{~cm}$. Among the morphometric measurements identified in the present study, weight had the highest coefficient of variation, while total length had the lowest (Table 1). Female and male individuals were evaluated together because there was no difference between their length or weight measurements (t-test; $\mathrm{P}>0.05$ ).

Total length and fish weight frequency distributions were also determined for the $O$. angorae specimens (Fig. 3). The total length-weight relationship was determined as $\mathrm{W}=0.014 \mathrm{TL}^{2.7359}\left(\mathrm{r}^{2}=0.9659\right)$ in all $O$. angorae specimens, and these results are presented in Figure 4. There was a strong relationship between the length and the weight values of the O. angorae specimens with a $95 \%$ confidence interval of $b$ that ranged from 2.7261 to 2.7435 . The length-length relationship showed that standard length, fork length, and total length were highly correlated with one another (Fig. 5). The TL-FL, TL-SL, and FL-SL relationship equations with the determination coefficient for $O$. angorae were $\mathrm{TL}=0.1341+$ $1.0301 \mathrm{FL} ;\left(\mathrm{r}^{2}=0.9914\right), \mathrm{TL}=0.2091+1.1646 \mathrm{SL}$; $\left(\mathrm{r}^{2}=0.986\right)$, and $\mathrm{FL}=0.0998+1.1261 \mathrm{SL} ;\left(\mathrm{r}^{2}=\right.$ 0.9868), respectively (Fig. 5). In the present study, the minimum and maximum condition factors of $O$. angorae specimens from the Perşembe Plateau meandering streams were 0.7012 and 1.0272, respectively, and the mean condition factor calculated was $0.8295 \pm 0.0079$. 

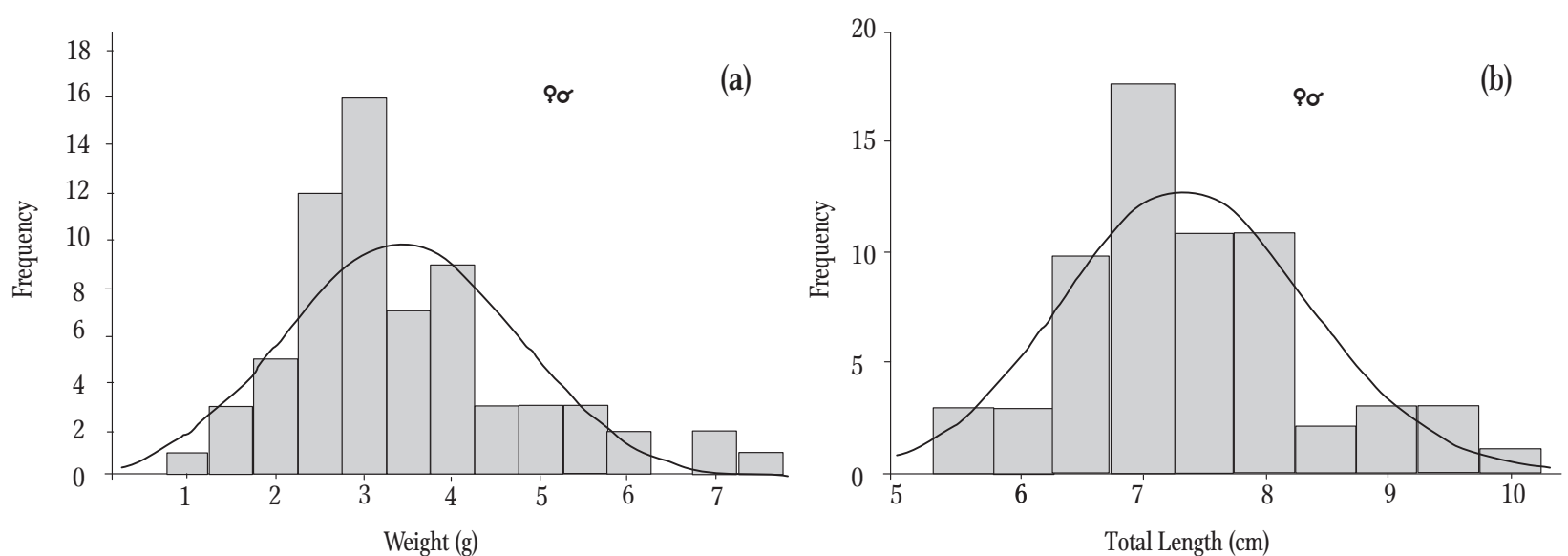

Figure. 3. Weight-frequency (a) and total length-frequency (b) distributions of Oxynoemacheilus angorae from the Perşembe Plateau meandering streams in Ordu, Turkey.

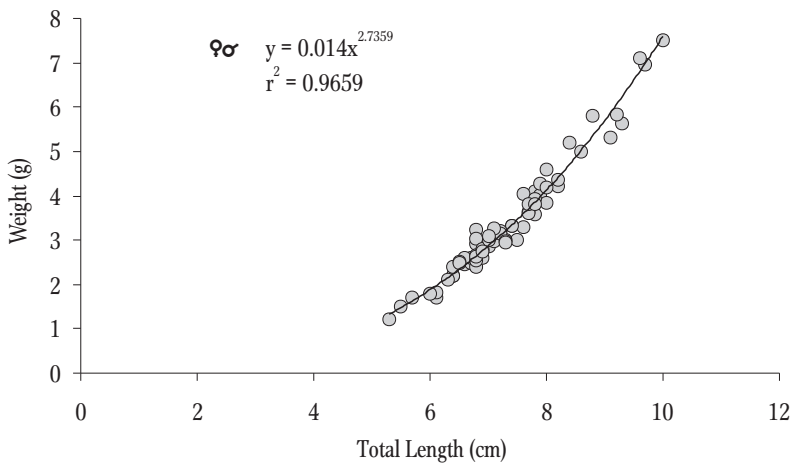

Figure 4. Length-weight relationship of Oxynoemacheilus angorae from the Perşembe Plateau meandering streams in Ordu, Turkey.

\section{Discussion}

The family Nemacheilidae is a large one with more than 600 known fish species. Oxynoemacheilus, which is a genus of this family, is represented by sixty species globally and more than half of these species occur in Turkish waters (Freyhof et al. 2021). However, a review of the literature indicated that there are a limited number of studies on the relationship of the Oxynoemacheilus species of this genus with length-weight, length-length and condition factors. In the present study, the maximum total length of $O$. angorae was $10 \mathrm{~cm}$, which is the largest reported $O$. angorae specimen in the literature. The total length and weight values of the species reported from different localities are presented in Table 2.
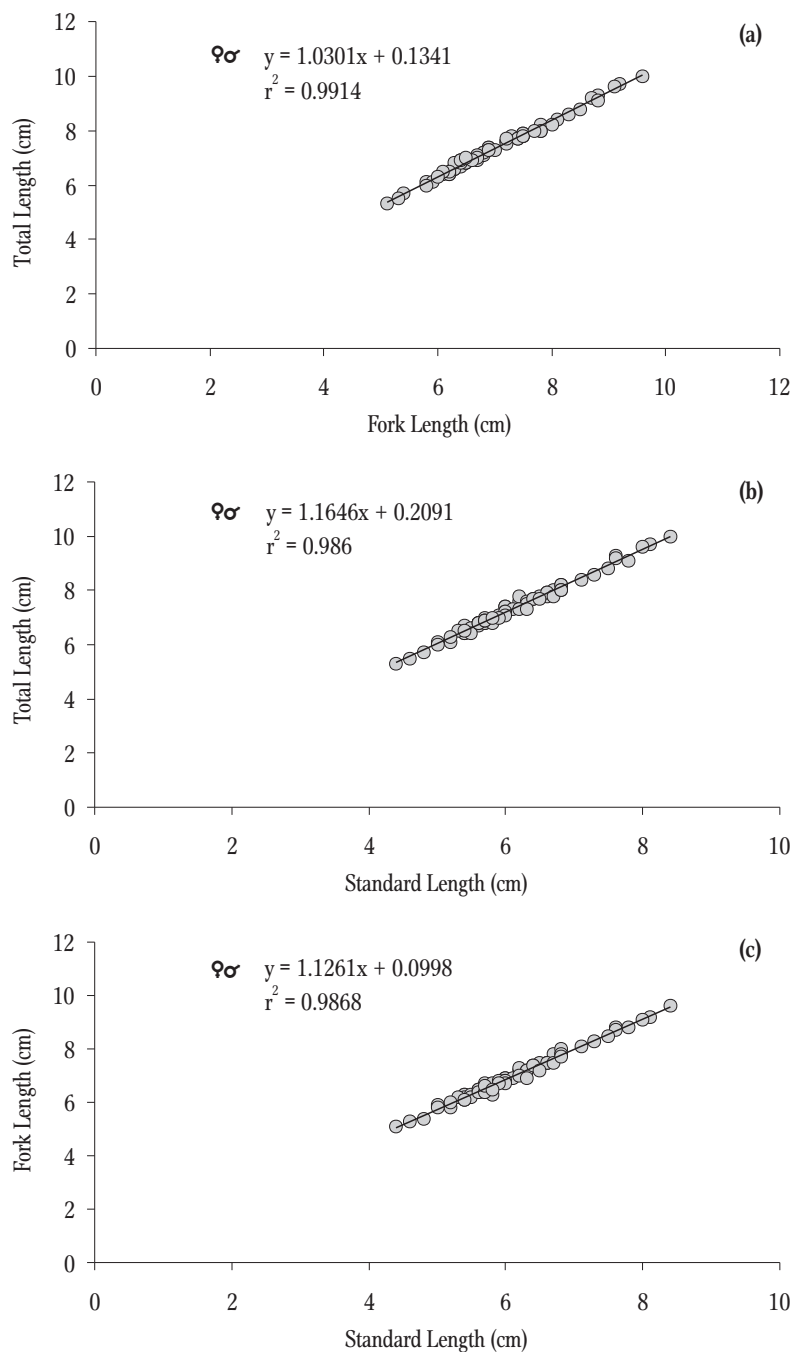

Figure 5. Total length-fork length (a), total length-standard length (b), and fork length-standard length (c) relationships for Oxynoemacheilus angorae from the Perşembe Plateau meandering streams in Ordu, Turkey. 
Table 2

Total length (TL) and body weight (BW) ranges for Oxynoemacheilus angorae populations in different habitats

\begin{tabular}{|c|c|c|c|c|}
\hline Locations & Sex & TL (min-max) & BW (min-max) & References \\
\hline Balıklı Stream & $9+\sigma^{x}$ & $3.8-7.6 \mathrm{~cm}$ & $0.53-4.21 \mathrm{~g}$ & Gaygusuz et al. 2013 \\
\hline Jajroud River & $q+o^{x}$ & $4.7-7.3 \mathrm{~cm}$ & $0.86-3.56 \mathrm{~g}$ & Golzarianpour et al. 2011 \\
\hline Sirwan River & $\varphi+\sigma^{\pi}$ & $4.3-8.2 \mathrm{~cm}$ & - & Hasankhani et al. 2014 \\
\hline Söğütözü Creek & $q+\sigma^{x}$ & $4.4-8.3 \mathrm{~cm}$ & $0.80-6.60 \mathrm{~g}$ & Erk'akan et al. 2014 \\
\hline Kirmir Stream & o $+\sigma^{x}$ & $4.4-9.6 \mathrm{~cm}$ & $0.61-6.67 \mathrm{~g}$ & Zencir and Korkmaz 2016 \\
\hline Kılıçözü Stream & o $+\sigma^{x}$ & $3.5-9.8 \mathrm{~cm}$ & $0.38-6.58 \mathrm{~g}$ & Yazıcıoğlu and Yazıcı 2016 \\
\hline Kızılırmak River Basin & o $+\sigma^{x}$ & $2.8-8.6 \mathrm{~cm}$ & $0.22-6.18 \mathrm{~g}$ & Birecikligil et al. 2016 \\
\hline Perşembe Plateau Meandering Streams & o $+\sigma^{x}$ & $5.3-10 \mathrm{~cm}$ & $1.20-7.51 \mathrm{~g}$ & This study \\
\hline
\end{tabular}

In fisheries studies, characteristics of the length-weight in fish species are that growth is isometric when the $b$ exponent is 3 , growth is negative allometric when $b<3$, and growth is positive allometric when $b>3$. The values of $b$ were within the limits of 2.5-3.5 that are reported commonly for many fish species by Froese (2006). The LWRs of Oxynoemacheilus species were reported from various aquatic habitats by many authors. For instance, O. eregliensis $(b=3.196)$ from Melendiz Creek, $O$. evreni $(\mathrm{b}=2.788)$ from Çayır Creek, O. mesudae $(b=2.628)$ from Küfe Creek, O. samanticus $(b=2.919)$ from Karaboğaz Creek, O. simavicus $(b=3.261)$ from Karaçaltı Creek (Erk'akan et al. 2014), O. hamwii $(b=3.52)$ from Gölbaşı Lake (Özcan and Altun 2016), and O. veyseli $(b=2.821)$ from Bozkuş Creek (Özdemir et al. 2019). Moreover, there are many data on $O$. theophilii that were reported from different freshwater habitats such as Bozcay Creek $(b=2.898)$, Dalaman Stream $(b=2.989)$, Cüneyt Creek $(b=3.07)$, Duger Spring $(b=3.188)$, and Yiğitler Creek $(b=3.293)$ (Innal et al. 2015). The variations in $b$ values from 3 were statistically significant for the $O$. angorae specimens from the current study and indicated negative allometric growth for the overall population $(\mathrm{P}<0.001)$. However, growth type varies for the same species occurring in different habitats. For instance, several studies reported that $O$. angorae had different growth types in different habitats (Table 3). There are many factors, such as nutrition, health status, stomach fullness, sex, gonad maturity, changes in water parameters, and even sample size that could have caused individuals of the same species to show different types of growth.

A linear relationship was obtained between the length measurements (TL-SL, TL-FL, and FL-SL) of O. angorae from the Perşembe Plateau meandering streams. The regression equation of length-length relationships was determined for $O$. angorae to assess symmetrical growth. The review of the literature indicated that the results obtained by other researchers were similar to those in the present study (Table 4). According to Fishbase (Froese and Pauly 2020), the maximum total length of $O$. angorae is $8.5 \mathrm{~cm}$, while in the current study, a new maximum total length of $10 \mathrm{~cm}$ for $O$. angorae was recorded.

The condition factor is one of the most important parameters representing the condition or well-being of fish. The condition factors of fish species of the same species occurring in different habitats can vary. A condition factor value of more than 1 indicates that the health condition of the fish individuals is good (Nash et al. 2006). In the present study, the average condition factor of $O$. angorae was calculated as $0.8295 \pm 0.0079$, and similar results were reported in several studies such as $0.86 \pm 0.009$ for the Kılıçözü Stream population (Yazıcıoğlu and Yazıcı 2016), $0.94 \pm 0.130$ for the Kiz1lirmak River Basin population (Birecikligil et al. 2016), and $0.9562 \pm$ 0.0349 for the Asartepe Dam Lake population (Saylar et al. 2020). Differences among the condition 
Table 3

Length-weight relationship parameters for Oxynoemacheilus angorae from different habitats

\begin{tabular}{|c|c|c|c|c|c|c|}
\hline Locations & Sex & $\mathrm{a}$ & $\mathrm{b}$ & $r^{2}$ & GT & References \\
\hline Balıklı Stream & $q+\sigma^{x}$ & 0.008 & 3.01 & 0.98 & - & Gaygusuz et al. 2013 \\
\hline Jajroud River & $q+\sigma^{\pi}$ & 0.006 & 3.237 & 0.88 & $\mathrm{~A}+$ & Golzarianpour et al. 2011 \\
\hline Sirwan River & $q+o^{x}$ & 0.011 & 2.81 & 0.96 & - & Hasankhani et al. 2014 \\
\hline Söğütözü Creek & $9+o^{x}$ & 0.0062 & 3.228 & 0.99 & - & Erk'akan et al. 2014 \\
\hline Kirmir Stream & q $+0^{x}$ & 0.015 & 2.73 & 0.88 & A- & Zencir and Korkmaz 2016 \\
\hline Kılıçözü Stream & $q+o^{x}$ & 0.0099 & 2.929 & 0.96 & I & Yazıcıoglu and Yazıc1 2016 \\
\hline Kızılırmak River Basin & $q+o^{x}$ & 0.008 & 3.102 & 0.94 & I & Birecikligil et al. 2016 \\
\hline Asartepe Dam Lake & $q+o^{x}$ & 0.0171 & 2.651 & 0.80 & A- & Saylar et al. 2020 \\
\hline Perşembe Plateau Meandering Streams & $q+o^{x}$ & 0.0140 & 2.74 & 0.97 & A- & This study \\
\hline
\end{tabular}

$\mathrm{a}$ and $\mathrm{b}$ : the intercept and slope of the regression line respectively; $\mathrm{r}^{2}$ : correlation coefficient; GT: growth type; I: isometric; A-: negative allometric; $\mathrm{A}+$ : positive allometric.

Table 4

Length-length relationship parameters for Oxynoemacheilus angorae from different habitats

\begin{tabular}{|c|c|c|c|c|c|c|c|}
\hline Locations & $\mathrm{n}$ & Sex & Equations & a & $\mathrm{b}$ & $r^{2}$ & References \\
\hline \multirow[t]{2}{*}{ Sirwan River } & \multirow[t]{2}{*}{44} & $q+o^{x}$ & $\mathrm{SL}=\mathrm{a}+\mathrm{bTL}$ & 0.000 & 0.855 & 0.980 & \multirow[t]{2}{*}{ Hasankhani et al. 2014} \\
\hline & & $q+o^{\pi}$ & $\mathrm{FL}=\mathrm{a}+\mathrm{bTL}$ & 0.000 & 0.948 & 0.990 & \\
\hline \multirow[t]{3}{*}{ Kirmir Stream } & \multirow[t]{3}{*}{197} & $q+0^{x}$ & $\mathrm{SL}=\mathrm{a}+\mathrm{bTL}$ & 0.957 & 0.957 & 0.807 & \multirow[t]{3}{*}{ Zencir and Korkmaz 2016} \\
\hline & & $++\sigma^{x}$ & $\mathrm{FL}=\mathrm{a}+\mathrm{bSL}$ & 0.073 & 0.073 & 0.819 & \\
\hline & & $q+o^{x}$ & $\mathrm{TL}=\mathrm{a}+\mathrm{bFL}$ & 0.139 & 0.139 & 0.978 & \\
\hline \multirow[t]{3}{*}{ Kılıçözü Stream } & \multirow[t]{3}{*}{103} & $q+o^{x}$ & $\mathrm{SL}=\mathrm{a}+\mathrm{bTL}$ & -0.102 & 0.855 & 0.986 & \multirow[t]{3}{*}{ Yazıcıoğlu and Yazıcı 2016} \\
\hline & & $q+o^{x}$ & $\mathrm{FL}=\mathrm{a}+\mathrm{bSL}$ & 0.203 & 1.12 & 0.987 & \\
\hline & & q $+0^{x}$ & $\mathrm{TL}=\mathrm{a}+\mathrm{bFL}$ & 0.022 & 1.02 & 0.997 & \\
\hline \multirow[t]{3}{*}{ Asartepe Dam Lake } & \multirow[t]{3}{*}{50} & $q+o^{x}$ & $\mathrm{FL}=\mathrm{a}+\mathrm{bSL}$ & 0.426 & 1.0503 & 0.890 & \multirow[t]{3}{*}{ Saylar et al. 2020} \\
\hline & & $q+o^{\pi}$ & $\mathrm{TL}=\mathrm{a}+\mathrm{bSL}$ & 0.404 & 1.1137 & 0.870 & \\
\hline & & $q+0^{x}$ & $\mathrm{TL}=\mathrm{a}+\mathrm{bFL}$ & -0.004 & 1.0525 & 0.960 & \\
\hline \multirow[t]{3}{*}{$\begin{array}{l}\text { Perşembe Plateau } \\
\text { Meandering Streams }\end{array}$} & \multirow[t]{3}{*}{65} & o $+0^{x}$ & $\mathrm{FL}=\mathrm{a}+\mathrm{bSL}$ & 0.0998 & 1.1261 & 0.987 & \multirow[t]{3}{*}{ This study } \\
\hline & & $q+o^{x}$ & $\mathrm{TL}=\mathrm{a}+\mathrm{bSL}$ & 0.2091 & 1.1646 & 0.986 & \\
\hline & & $q+o^{x}$ & $\mathrm{TL}=\mathrm{a}+\mathrm{bFL}$ & 0.1341 & 1.0301 & 0.991 & \\
\hline
\end{tabular}

TL: total length; FL: fork length; SL: standard length; $\mathrm{r}^{2}$ : coefficient of determination; $\mathrm{n}$ : sample size; a and b: the intercept and slope of the regression line respectively.

factors of fish specimens of the same species could result from the effects on the condition factor of habitat differences, sample size, or sampling time. Additionally, it also provides information to researchers on different topics such as condition factors, population density, nutritional status, and the impact of climate change on growth (Froese 2006). However, in the current study, the average condition factor of $O$. angorae specimens $(0.8295 \pm 0.0079)$ was determined to be less than 1 . This value was the lowest value reported for this species to date in the literature. There could be many reasons for this, including changes in habitat, food availability, season, fish age, and shape (Ricker 1979).

The current study indicates some population characteristics of $O$. angorae from the Perşembe Plateau meandering streams in Ordu, Turkey. The fact that the condition factor value was below the welfare level showed that this species was encountering some problems in the habitat and that these 
adversely affected the development of the fish. The fact that this species is listed in the category of least concern on the IUCN list, and that it might have encountered some problems in the Perşembe Plateau meandering streams shows that the results of the present study are very important. The Perşembe Plateau is a popular tourist attraction where tourism continues throughout all seasons of the year, and it is a protected habitat and a potential candidate for designation as a UNESCO World Cultural Heritage site (Bahtiyar Karadeniz and Sar1 2018). It is recommended to investigate and monitor whether factors such as tourism activities, animal husbandry, and water pollution of the Perşembe Plateau meandering streams are some of the causes of these problems in O. angorae.

Author Contributions: S.Y., D.B. and N.P. conducted the field study collection and analysis, S.Y. designed the study and the concept, S.Y. and D.B. drafted and revised the manuscript.

\section{ORCID iD}

Serdar Yedier iD https://orcid.org/0000-0003-0017-3502

\section{References}

Bagenal, T. B., Tesch, F. W. (1978). Age and growth. In: Methods for assessment of fish production in freshwaters (Ed.) T.B. Bagenal, Blackwell Scientific Publications, Oxford: UK, 101-136.

Bahtiyar Karadeniz, C., Sari, S. (2018). Evaluation of tourism potential based on natural resources of Ordu province. The Journal of International Social Research, 61, 741-759 (in Turkish).

Birecikligil, S. S., Çiçek, E., Öztürk, S., Seçer, B., Celepoğlu, Y. (2016). Length-length, length-weight relationship and condition factor of fishes in Nevțehir Province, Kızılırmak River Basin (Turkey). Acta Biologica Turcica, 29(3), 72-77.

Erk'akan, F., Innal, D., Özdemir, F. (2014). Length-weight relationships for some endemic stone and spine loach species in Anatolia. Journal of Applied Ichthyology, 30, 244-245.

Freyhof, J. (2014). Oxynoemacheilus angorae. The IUCN Red List of Threatened Species 2014: e.T14493A19849461.

Freyhof, J., Yoğurtçuoğlu, B., Kaya, C. (2021). Oxynoemacheilus sarus, a new nemacheilid loach from the lower Ceyhan and Seyhan in southern Anatolia (Teleostei: Nemacheilidae). Zootaxa, 4964(1), 123-139.

Froese, R. (2006). Cube law, condition factor and weight-length relationships: history, meta-analysis and recommendations. Journal of Applied Ichthyology, 22(4), 241-253.

Froese, R., Pauly, D. (2020). FishBase. Species list: World Wide Web electronic publication. Available from https://www.fishbase.se/summary/25993 Accessed 5 Janurary 2021.

Gaygusuz, Ö., Aydın, H., Emiroğlu, Ö., Top, N., Dorak, Z., Gürsoy Gaygusuz, Ç., Başkurt, S., Tarkan, A. S. (2013). Length-weight relationships of freshwater fishes from the western part of Anatolia, Turkey. Journal of Applied Ichthyology, 29(1), 285-287.

Golzarianpour, K., Abdoli, A., Kiabi, B. H. (2011). Length-weight relationships for nine nemacheilian loaches (Teleostei: Nemacheilidae) from Iran. Journal of Applied Ichthyology, 27(6), 1411-1412.

Hasankhani, M., Keivany, Y., Daliri, M., Pouladi, M., Soofiani, N. M. (2014). Length-weight and length-length relationships of four species (Barbus lacerta Heckel, 1843), Oxynoemacheilus angorae (Steindachner, 1897), Squalius lepidus (Heckel, 1843) and Pseudorasbora parva (Temminck \& Schlegel, 1846) from the Sirwan River (western Iran). Journal of Applied Ichthyology, 30(1), 206-207.

Innal, D., Özdemir, F., Dogangil, B. (2006). Length-weight relationships of Oxynoemacheilus theophilii (Teleostei: Nemacheilidae) from Turkey. International Journal of Fisheries and Aquatic Studies, 2: 249-250.

Nash, R. D., Valencia, A. H., Geffen, A. J. (2006). The origin of Fulton's condition factor-setting the record straight. Fisheries, 31(5), 236-238.

Özcan, G., Altun, A. (2016). Length-weight and length-length relationships for four freshwater fish species from Gölbațı Lake (Hatay), Turkey. Journal of Applied Ichthyology, 32(6), 1350-1352.

Özdemir, F., İnnal, D., Erk'akan, F. (2019). Length and Weight Parameters of The Loach, Oxynoemacheilus veyseli (Nemacheilidae) in Bozkuş Creek (Kars-Turkey). Menba Journal of Fisheries Faculty, 5, 1-5.

Ricker, W. A. (1975). Computation and interpretation of biological statistics of fish population. Bulletin of the Fisheries Research Board of Canada, 191, 1-382.

Ricker, W. E. (1979). Growth rates and models. In: Fish Physiology, III, Bioenergetics and Growth (Ed.), Hoar W. S., Randall D. J., Brett J. R., Academic Press, London, 677-743.

Sarkar, U. K., Negi, R. S., Deepak, P. K., Lakra, W. S., Paul, S. K. (2008). Biological parameters of the endangered fish Chitala chitala (Osteoglossiformes: Notopteridae) from some Indian rivers. Fisheries Research, 90(1-3), 170-177. 
Saylar, O., Ata, B., Firidin, B. (2020). Some population characteristics of Oxynoemachellus angorae (Steindachner, 1897) living in Ankara Asartepe Dam Lake. Journal of Anatolian Environmental and Animal Sciences, 5, 711-716 (in Turkey).

Yazıcıoğlu, O. (2016). The Length-Weight, Length-Length Relationship and Condition Factor of Angora Loach, Oxynoemacheilus angorae (Steindachner, 1897) Inhabiting Kılıçözü Stream in Kızılırmak River Basin (Central Anatolia-Turkey). Turkish Journal of Agriculture-Food Science and Technology, 4(12), 1165-1168.

Yedier, S., Kontaş, S., Bostancı, D. (2019). Condition factor, length-length and length-weight relationships for Pagellus acarne (Risso, 1827) inhabiting the Sea of
Marmara. Journal of Anatolian Environmental and Animal Sciences, 4, 82-88 (in Turkish).

Yılmaz, S., Polat, N., Yazıcıoğlu, O. (2010). Length-weight and length-length relationships of common carp (Cyprinus carpio L., 1758) inhabiting inland waters of Samsun province. The Black Sea Journal of Sciences, 1, 39-47.

Yilmaz, S., Polat, N. (2011). Length-weight relationship and condition factor of Pontic shad, Alosa immaculata (Pisces: Clupeidae) from the southern Black Sea. Research Journal of Fisheries and Hydrobiology, 6(2), 49-53.

Zencir, Ö., Korkmaz, A. Ş. (2016). Length-Weight and Length-Length Relationships of Fish Species in Kirmir Stream and its Tributaries (Suveri and Ilhan Stream) of Sakarya River, Turkey. Journal of Applied Biological Sciences, 10(1), 55-60. 